\title{
ЛИТЕРАТУРОВЕДЕНИЕ
}

\author{
UDC 82
}

Samir Hajj

\section{THE MUSIC IN THE WORKS OF JABRA IBRAHIM JABRA AND THE INFLUENCE OF JAMES JOYCE'S WRITINGS}

Academic Institute for Arab Teacher Training, Beit Berl College, Kfar Saba 44905, Israel

This article will examine the intensive use of reference to music in the works of the Palestinian novelist Jabra Ibrahim Jabra. It will show that the reference to music in his works displays two functions: the first is technical in order to stimulate the memory and recuperate distant memories of past events and the second is denotative and interpretative of the text. This paper will show also the impact of James Joyce's writings on the novels of Jabra in the use of reference to music. Jabra used the reference to music as a creative procedure in his novels; first in A Cry in a Long Night (1946), then in his short story collection Araqwa-Qișaș Ukhra (1956) and in Hunters in a Narrow Street (1960). Furthermore, his two novels The Ship (1970) and In Search of Walid Masoud (1978) show the highest level of use of reference to music in the Arab novel in general. Refs 16.

Keywords: Arabic prose, Palestinian prose, music in literature, Jabra Ibrahim Jabra, James Joyce.

\section{МУЗЫКА В ПРОИЗВЕДЕНИЯХ ДЖАБРЫ ИБРАХИМА ДЖАБРЫ И ВЛИЯНИЕ НА НЕГО ТВОРЧЕСТВА ДЖЕЙМСА ДЖОЙСА \\ Самир Хадж}

Академический институт по подготовке преподавателей арабского языка, колледж Бейт-Берл, Кфар Саба, 44905, Израиль

В статье рассматривается активное использование музыкальной тематики в произведениях известного палестинского прозаика Джабры Ибрахима Джабры. Обращение к музыке выполняет в его сочинениях две функции: техническую - порождение воспоминаний и реконструкция событий далекого прошлого и смысло-интерпретационную в отношении самого текста. В статье также показывается влияние произведений Джеймса Джойса на творчество Джабры - именно в плане использования музыкальной тематики. Это, в частности, касается романов Джабры «Крик в долгой ночи» (1946), «Охотники на узкой улице» (1960), рассказов сборника «Пот и другие рассказы» (1956). А в романах Джабры «Корабль» (1970) и «В поисках Валида Масуда» (1978) обращение к музыке является наиболее интенсивным в арабской романистике вообще. Библиогр. 16 назв.

Ключевые слова: арабская проза, палестинская проза, музыка в литературе, Джабра Ибрахим Джабра, Джеймс Джойс.

Jabra is considered as one of the first Arab writers to reference music as a theme and creative procedure, first in his novel A Cry in a Long Night (Surakh fi Layl Tawil) ${ }^{1}$ which

\footnotetext{
1 All translations from Arabic texts are my own unless otherwise noted.

(c) Санкт-Петербургский государственный университет, 2016
} 
he wrote in English in $1946^{2}$, then in his short story collection Araqwa-Qisas Ukhra (Sweat and other Stories) (1956) and in Hunters in a Narrow Street which he published in English in 1960. Furthermore, his two novels The Ship (1970) and In Search of Walid Masoud (1978) show the highest level of use of musical references in the Arab novel and both can be considered as musical novels. Jabra used the reference to music in the description and identification of the characters and in the exploration of their inner world. In the following pages I will show that the reference to music in the works of Jabra displays two functions: the first is technical to awaken memory and recall distant memories of past events; and the second is denotative and interpretative of the text. I will also show the impact of James Joyce's writings on the novels of Jabra Ibrahim Jabra.

\section{Music in al-Safinah (The Ship)}

Music in The Ship is used as a technique to draw and define the characters through allusions. Like other techniques used in the novels employing the stream of consciousness technique, it portrays and reveals what is happening in the mind and heart of the characters. The musical allusions in The Ship perform a connotative function in the narrative text, contribute to revealing the theme and provide information about the character, time and the place. What is important in the use of reference to music in the works of Jabra in general and in The Ship in particular that it generates flashbacks, revives and brings back to life memories in the mind of the narrating character and comes accompanied by image and descriptions of nautical scenes:

The moon had disappeared, and the vast expanse of the sea blackened under the sheen of the huge agglomeration of stars. The monotonous rhythm of the ship's engine was clearly audible deep down in the ship. Amid this torrent of hatred Luma sprang up before me dressed or naked, I could not tell. She had her clothes on, but I could see every part of her body. [1, p. 15]

The music originating from the bottom of the sea vessel paved the way to Isam Salman to remember one of his love stories with Luma Abdul-Ghani, when he accompanied her in his car into an abandoned field outside Baghdad and the car broke down. The music was associated with sex and it revived sexual scenes from his memory. The loud music also brought back to life the memories of Wadi 'Assaf during the dancing party in the ship while Jacqueline was in his arms. He remembered the shooting of his 14 year-old friend Fayiz by Jewish soldiers during the events of 1948, in addition to evoking the life of Jesus Christ. This was narrated over twenty four pages:

When the music became more intense and wild, she threw herself on to my chest as if she wanted to squeeze herself between my bones. I remembered Fayiz, I remembered the rocks. I remembered death and birth. [1, p.64-65]

The music that was used at the end of the retrieval ignited the memory of Wadi 'Assaf and made him recall the sad and painful memories from his childhood in Jerusalem. The music was the link between Wadi 'Assaf and his hometown Jerusalem and through it he goes back to a distant past stretching more than twenty years. It brings him back to his consciousness to narrate detailed memories about his beautiful childhood before the

\footnotetext{
2 Published in Arabic in 1955.
} 
death of his friend Fayiz. The music with Wadi is combined with the realization of his dream of returning back to his home. It carries hints and signals of the Return. Fernando returned to his homeland his violin under his arm, and Wadi dreams of returning to his homeland to form a musical choir to play and dance with his folks. He will also carry with him to his homeland the records of masterpieces of Western music of the nineteenth and twentieth centuries.

Of course I shall buy a thousand records and listen to Vivaldi, Bach, Telemann, Josquin des Prez, Brahms, Sibelius, Stravinsky and modern electronic music. [1, p. 76-77]

This intense mention of names of Western music masters refers to the cultural background of Wadi that in turn represents part of the musical culture of the author Jabra Ibrahim Jabra and his familiarity with Western Music in addition to his passion for it. Consequently, we can conclude here, that the reference to music in The Ship was coupled with homesickness and dream of return. The Palestinian Wadi Assaf who lives in a forced exile is the most passionate and knowledgeable of Western music and is addicted to it, in order to make him overlook his alienation. Music, in addition of being a narrative technique, it helps to provide information about the characters and reveals their inner worlds. In The Ship music plays also an anesthetic function, it eases the pain of alienation. This function was expressed in the words of Wadi in calling music a drug: "Music is my Hashish, I'm addicted to it." [1, p. 77]

The musical allusions in The Ship help in the communication of the theme indirectly. When the storm struck and the sea was raging Luma was suffering from seasickness and Isam after his departure from her roomn heard a sad Iraqi melody:

From the depths of the relentless storm I could hear an old Iraqi song. The words suddenly came back to me - I never thought that I would remember them: "If you pass over my grave, my love, my bones will quiver". I buried my face in the pillow. [1, p. 132]

This sad Iraqi musical melody in colloquial Arabic shows the physical and psychological condition of Luma. Her body is sick because of a sea storm, and she is psychologically tired as a result of her failed relationship with Isam. Her planned meeting with him revivified her memory about her love affair with him. This sad music in the Iraqi melody refers to the tragedy of Luma. It is also a clear indication to what Isam expected and referred to it in anticipation before it happens: Faleh committed suicide:

As for senora Luma, her beauty will only end in tragedy." No one knew about my relationship with Luma. [1, p. 28]

Musical allusions sometimes are made by citing the name of a song or some of it words in the original language of the song. In the chapter narrated by the Italian Emilia Vernizi, she recites Italian words from the opera Lucia di Lammermoor of the Italian musician Gaetano Donizetti (1797-1848). The citation of foreign words is termed by the North African linguists tahjin (hybridization), because it combines two different languages in one text and it represents a kind of intertextuality. Emilia says that if Faleh came alone in the trip, she would have taken him to the Scala in Milan to see Donizetti's Lucia di Lammermoor:

"Ah Edgardo," sings Lucia in the mad scene, "E te amo ancor, Edgardo mio", I still love you, Edgardo, I have always loved you... "Ah! Non fuggire”, for mercy's sake, do not run 
away,...Edgardo". Whereupon she stabs herself... who besides the Italians can sing with such magnificence, such power, such insane bravura?" [1, p. 164]

The musical allusions to this song, in particular reference to the insane love Lucia harbours for Edgardo which led her to commit suicide, reflect the psychology of Emilia in love with Faleh and represent the message that Emilia wants to deliver to him. They also allude to the suicide that Faleh committed later on. The suicide of Lucia in the song is only a hint in anticipation of what will happen in following chapters in The Ship, as other texts did in the novel, like the words of Faleh about the novel of Dostoevsky The Demons. [1, p. 107-112]

Emilia loved Faleh after they met in secret in Beirut. She was hoping to marry him:

I was sure he would marry me one day and felt even more confident than ever when he told me that he was studying Italian in his spare time and trying to read Pirandello! [1, p. 163]

She compared her love to him with the love of Lucia in the Opera of Donizetti:

"Do you want me to kill myself for you sake?" I asked suddenly and sat in the bath. [1, p. 164]

This overwhelming use of reference to music is due in my view to the influence of the novel of James Joyce, Ulysses, which included an excessive reference to music in the chapter entitled "Sirens". [2, p.548-629] Zack R. Bowen has established 158 references to music and 47 songs used by Joyce in this chapter. The two songs "The Last Rose of Summer" and "M'appari" taken from the opera of the German composer Friedrich von Flotow's Martha (1883-1812) were repeated in this chapter four times. [3, p. 88] In the same way, the word music in The Ship was repeated 13 times [4, pp. 19, 20, 24, 48, 71, 79, $94,108,120,190,201,203,217]$, the word "tune" 10 times and the word "song" 5 times. The names of ten musicians, nine European and one Arab singer were mentioned in one page [4, p.77]. James Joyce also made references in his novel Ulysses to popular songs (ballads); operas of the Irish musician Mikhail Balf mainly the Bohemian Girl [4, p. 259]; the Italian Vincenzo Bellini (1801-1835) [4, p. 258]; and the German musician Richard Wagner. [4, p. 550]

The music in Ulysses motivates sex in the imagination of Bloom in the chapter entitled "Nausicca", and this type of music according to Bowen is in line with the event. In the bars and scenes of prostitution loud music is used, and the title of the song delineates the personality of the singer. The song of the "Prostitute" was sung by a prostitute. [3, p.20] In the ship this phenomenon is repeated. The non-stop noise of recorded music that Faleh and Emilia Vernizi heard in the discotheque in Rawsha, drinking whiskey and kissing Emelia in the murky red light are sexually suggestive. [1, p. 163] In the dancing party which was held in the ship, the loud music was used for its sexual connotations when Jacqueline threw herself on to the chest of Wadi' [1, p. 64]. Isam Salman also, before having sex with Luma in his cabin inside the ship [1, p. 175] heard with her loud and flagrant music:

The guitar players sang loudly and enticingly, twisting their bodies as they screeched and screamed" [1, p. 173], and the dancers in the club "kicked up their legs and shook their buttocks. One girl after another stripped to the beat of drums and guitars [1, p. 171]. 
It can be said that music is present in a variety of forms in this novel in all of its chapters and most characters. The body of the thirty year old French Jacqueline is full of music in the eyes of Wadi 'Assaf [1, p.31-32], and the music is in harmony with the movements of the body as it appears in the body of Luma Abdul-Ghani while dancing with the song of the Egyptian singer Umm Kulthum at the front of the ship in front of the travellers:

Everyone was watching that sensational body bursting out of the tight-fitting dress, twisting, undulating and wriggling, without the slightest sense of shame. Luma danced on - her breasts quivering, waist swaying and her buttocks flexing above those long, slender thighs, that kept bending and straightening in time to the music. It was difficult to decide which part of her body to concentrate on. [1, p. 85]

The words used to describe the dance of Luma in the ship have the same form, rhythm and connotation with the movement of her body and music. They are repeated recursively like "watching, bursting, fitting, twisting, undulating, wriggling, quivering, swaying, flexing, bending, and straightening" in order to create a musical language. This style was one of the characteristics of the novel of James Joyce's masterpiece, Ulysses, in which he repeated words, paragraphs, phrases and topics. He initiated several paragraphs in several pages with question words like "what", "how", "where", "why" in order to create a musical language. [4, p. 666-737] Some critics believe that this technique was borrowed by James Joyce from the German Musician Richard Wagner (1813-1883). [5, p.37] Ulysses in the eyes of Martin Ross is like a great Symphony because of its rhythmic movement. [6, p. 5]

\section{Surakh fi Layl Tawil (A Cry in a Long Night)}

In the novel Surakh fi Layl Tawil [7] (A Cry in a Long Night) the music is represented in the form of a piece of furniture in the house of an urban family. When the father of Sumayah visited her with her husband Amin, he offered her a piano as a gift. [7, p. 49] Music in this novel is represented as the "daughter" of the city. According to Amin, music and art in the city drives it forward, while people in the villages still look to music with disdain. The grandfather of Sumayah used to sing and compose musical songs privatelyat that time (referring to the period of the Ottoman rule in Palestine), while the rural community looked at music and singing with contempt:

... despite his veneration for music and musicians, he was afraid that if the villagers

living around him knew about his songs, they will stop respecting him. [7, p. 26]

Music in most of the works of Jabra stirs memory and allow the characters to retrieve sweet memories from their past. Ayman after listening to the music from the radio recovers his memories of past events when he used to play music with Sumayah:

When I sat down at one of the tables, the radio was broadcasting faint music ... it brought to my mind the docile afternoons and evenings that I spent quietly with Sumayah, while we were playing our favorite records. [7, p. 30]

Like the works of James Joyce, the music that retrieves past memories in this novel is quiet and low. It retrieves sexual memories also. Amin retrieved from his memory his romance with Sumayah to the rhythm of the gramophone which reappears frequently 
in the work of Jabra. This instrument was the only device available at the time in the urban houses. The music which recalls sexual scenes is always accompanied with beautiful landscapes, sun, clouds, rain, windows and an attractive body.

In the short story collection Araq and Other Stories consisting of twelve stories, music is used in eight of them in varying forms. These are sometimes in a marginal manner like mentioning few words by the characters and other times by an elaborate description of a musical instrument, its nature and its impact on the listener. The titles of three stories in this collection carry musical connotations: "Singers in the Dark", “The Gramophone”, and "A Passionate Man about Music".

In the short story Singers in the Dark, Jabra borrowed the title from the novel of James Joyce A Portrait of the Artist as a Young Man (1916), and in particular from the article of the critic Alex Aronson in which he describes Steven's brothers singing while sitting in the kitchen around the tea table: "Frequently it is the sound of people singing in the dark". [8, p.44] Stephen heard in their singing a tone of agony and pain. Jabra used in this story the popular song "Dalounah..Dalounah" and the music was accompanied by drinking Araq, the local alcoholic drink in Bethlehem, to denote the Christian identity of the participants. The name of the characters in the story, like the name of the children, Salloum, Moses and Elias, support this conclusion. The instrument used to play the music was the oud (lute) which fits the type and place of the song. The music is presented in the story through a detailed description of the player and the instrument which led to the suspension of the narrative discourse.

The player on the oud was exhilarated with what he sings and drinks. His head reclining over the oude and the plume between his fingers hits the strings, creating ding-dong sounds that tumble and flip-flop with the sounds of the singers. [9, p. 39]

In fact, the Western music overwhelms most of the works of Jabra, while the use of folk songs was trivial. Perhaps, the use of the folk song in Singers in the Dark is due to the influence of the works of James Joyce. Another phenomenon which supports the influence of the works of Joyce on this collection is the music of cafes and bars. In the short story "The Gramophone" he describes Yusuf as a passionate man about music from the beginning of his life, since he started to stop at the doors of cafes to listen to the music emitted from there. This short story shows that the affection for music has nothing to do with poverty or wealth. Yusuf was poor and worked in casting zinc, and lived in a wooden hut not worthy of a dog, but he has a gramophone and a pile of records. This is what Yacub saw when Hanna the plumber sent him to Yusuf's house to call him:

My eyes suddenly fixed on a pile of records near a blue box that I immediately realised that this is a gramophone. It appeared there is no relationship between this person covered with patches and the records or the gramophone. [9, p. 53]

The interest in Western music and classical musicians such as Beethoven and Mozart as shown by the characters of the stories was repeated in other stories like Multaqa alAhlam and As-Suyulwa al-Anqa'. In Multaqa al-Ahlam, Anwar Karim the owner of the palace who returned from England to his home town Jerusalem in 1946 listens to the music of Beethoven and Mozart. In As-Suyulwa al-'Anqa', Jameel shows his musical inclinations during his studies at Cambridge University. Music for him resuscitates awareness, thoughts, feelings, passion and increases concern: 
Music did its own effect on me; it has increased my concerns, revitalised my thoughts and tossed my mind in the midst of varieties of sensations. [9, p. 187]

The music in the eyes of Jameel penetrated deep into the consciousness of his girlfriend Sheila. He used to accompany her during his studies at Cambridge to the "Dorothy Café":

Sheila at that moment was sleeping on the bed with her clothes. Perhaps the music leaked to her from the living room where we were sitting and penetrated into the depths of her dark consciousness. Perhaps when John Peters stopped playing she felt the waves of dormancy wash back to flood her. [9, p. 187]

The use of words and phrases such as "leaked", "penetrated to the depth of her dark consciousness", "waves of dormancy" and assigning these actions to music refers to the stream of consciousness style, which is concerned with the discovery of the subconscious of the human being following the emergence of new theories in psychology. The music visualises the inner persona of Sheila through a psychological depiction to reveal her inner temperament to us and the ideas occupying her consciousness. The use of expressions like "penetration of music to the depths of her dark consciousness" refers in my view to the influence of the novel of James Joyce: A Portrait of the Artist as a Young Man on this story. A quite similar text and vocabulary are used in the work of Joyce in which he describes the penetration of music into the fabrics of the mind like dissolving towers of sand:

The music passed in an instant, as the first bars of sudden music always did, over the fantastic fabric of his mind, dissolving them painlessly and noiselessly as a sudden wave dissolves the sand-built turrets of children. [10, p. 160]

Accordingly, A Portrait of the Artist as a Young Man can be considered in terms of Gérard Genette (1930) as the "hypotext" and the As-Suyulwa al-Anqa' is the "hypertext". However, the reference to music reaches its peak in the short story "The Passionate Man about Music". This man became rich, built a house on the top of a high summit, moved his countless packages records there and bought an electric generator to use for an automatic gramophone. One day he placed many records of Johann Sebastian Bach in the gramophone, raised the amplifiers to the highest level, kept running between the stones, and then threw himself in a deep trench and died. He left a message in which he wrote that he tore up all his money in order that no one will suffer from its misery. The music as presented in this story is eternal and does not die, it is clamorous in contrast combined with the nature of mountains, gorges, rocks and stones. The man died and the music remained playing for a long time and realised an important role in the death of the man and his union with the nature; embodying the principle of pantheism as a religious philosophy combining the existence of gods with nature. According to this belief, the divine exists in all things, mainly in the manifestations of nature such as trees and rocks, a belief that is associated with pagan religions in general.

The music in "The Passionate Man about Music" is the reason for insurgence and rejection of the physical life of the city. The man rebelled and defied the material world by shredding his money and resorting to the distant rocks away from human greed.

Once I finish tearing them, I will go out with the music of Bach to the rocks that have not been stained by the greed of human beings. I will not come back, because I will make myself food for the vultures. [9, p. 201] 
The choice of the music of Bach known for its religious nature is a referral to a religious reference which shows the Christian background of the man. There are other indications in the text which prove this, including the analogy of the singing hymns from the top of the mountain with the voices of angles:

...the music was launched around the spacious highlands, and the air started to rumble with the hymns, as if hundreds of angels had fallen from the sky with their background to play for him while he is wandering among the rocks. [9, p. 206]

The text points out that the spirit of the man set off to the supreme heavens. The choice of the man in his message the phrase "I will make myself food for vultures" is a reference to the words of Jesus in the Gospel of Matthew [11, 28: 24] when he answered his disciples on their question about the time and the signs of his coming: "Wherever there is a carcass, there the vultures will gather". The music of Bach in the view of this man is a self-search for immortality:

He sees in the succession of his melodies with geometrical composition a search of the human soul for immortality and eternity. [9, p. 206]

"The Passionate Man about Music" is a story of a man without known identity, without specifying the place and time except that he lived in the time of Johann Sebastian Bach or after him. The story manifests the innovative and successful use of music in modern Arab stories. The role of music in this story, published in 1956 at the beginnings of the literary life of Jabra, exceeded the physical description of a musical scene or a piece of furniture, into a flow inside the self and consciousness, reviving anxiety, then it reached the peak with the union with nature and eternity. It comprises an intensive use of musical expressions, as the word "music" is repeated nine times, the word "records" six times, and the words "gramophone" and "tune" three times. In the story "Nawafith Mughlaqah", music is used after love making. The hero makes love with his girlfriend Amira, then he goes to the house of Afif al-Asmar to listen to him playing violin. [9, p. 88]

\section{Hunters in a Narrow Street}

This novel was published in 1960 in English under the title: Hunters in a Narrow Street [12], and was translated into Arabic in 1974. It is an extended work of his story "The Sounds of the Night" written by Jabra in 1953, and included in his short story collection 'Araq and Other Stories' (1956). This novel is similar to the novel of James Joyce A Portrait of the Artist as a Young Man. Both novels are monophonic and autobiographical. In Hunters in a Narrow Street, Jameel Farran is the narrator and in A Portrait of the Artist as a Young Man Stephen Dedalus is the narrator and alienation in both works represent the same motif.

It is interesting to note that Joyce repeated the character of Stephen Dedalus in more than one literary work. He used the same name in A Portrait of the Artist as a Young Man and in Ulysses. This phenomenon was followed by Jabra in more than one novel, though he had given different names to this character which identifies with the personality of the author. In the works of Jabra there is a great similarity between the character of Jameel Farran in Hunters in a Narrow Street, Wadi 'Assaf in The Ship and Walid Masoud in In Search for Walid Masoud. The three are Palestinian Christians, their roots are from Bethlehem and Jerusalem and they live in the Arab world. This shows that Jabra was influenced by 
Joyce in the duplication of characters that are similar to him, but differed with him by giving his characters different names.

As the novel was written in English, the use of Western music was highlighted, with ceremonial connotations, such as the Funeral March of Frederic Chopin (1849-1810) which was played in the funeral of Emil Habash, a rich man from Bethlehem. The sad funeral music was convenient for the event and reflects the psychological state of the characters, in addition to the prestige and aristocratic status of the deceased. The choice of this aristocratic music carries hints and suggestions, and sometimes represents an anticipated precursor, as it turned out from the red paper placed in the centre of the record. It was a reference to the scene of the guillotine which represents the execution process in the symphony of the French musician Louis Hector Berlioz (1803-1869) that Adnan listened to it before his attempt to commit suicide with Hussien at the Tigris River:

'I bent over the gramophone to see what the record on it was, Adnan said, "I was playing that before I came to you."

"What is it?"

"It's part of La Symphonie Fantastique by Berlioz. The guillotine part. Do you know it? The artist imagining himself being guillotined. And then the terrifying Dies irae . Like this: tum...tum...tum..." He sang the solemn melody. "A great tune and the artist's descent into hell... I have always loved to see hell'. [12, p. 124]

The music of this symphony is sad, it refers to the death penalty and hinted to the attempt of suicide which Adnan committed later. When Adnan and Hussein were attempting suicide, the musical rhythm which we heard was loud and noisy, a sign of the intensity and severity of the event:

Music from a cabaret a few yards above us pulsated like madness against my head. [12, p. 218]

After they survived from drowning, the rhythm of the music was quiet, a sign of joy, and the musical instrument was replaced by the oriental oud which was more harmonic with the dancer movement. This is what Adnan and Hussein saw when they entered the nightclub:

"To the accompaniment of the oud a female in the limelight was going through her belly-wiggling and breast-shaking”.[12, p. 219]

As previously noted, the music of nightclubs and bars is recurrent in the texts of Jabra like the texts of James Joyce. In Ulysses, Leopold Bloom heard the music of singing men in the bar, while in Hunters in a Narrow Street, the joyful vibrant music and dance in the club, helps Adnan to return to the real world and free himself from the idea of committing suicide. Sometime the music is used to create irony and humour. This is how the novel represents a blond hair and blue eyes character, the English Brian Flint trying to learn how to play on an oriental instrument made of a pair of reeds, known as the al-matbaj. This instrument is used by the Bedouins in the desert:

It was a comic and sometime rather uncanny sight to see the fair-haired blue-eyed Oxford graduate bulge his cheeks lustily and blows away at the silly thing like a Bedouin in a wedding. [12, p. 226] 
The music here helps in understanding the text and interpreting the event. In popular places and occasions, the loud music, like the sounds of trumpets, drums and mastodons are a sign of movement and characteristic of the oriental identity of Iraqi society, as they reveal the inner world of the characters. The use of the South American music tango and paso doble in the garden of the house of Sulafa is a hint of her frustration. She was prevented from going to school and received private lessons at home.

\section{In Search for Walid Masoud [13]}

Western music in this novel forms the cultural identity of a Palestinian Christian character named Walid Masoud. The source of his musical and cultural background goes back to his Christian upbringing in which music was used in the church for prayers and worship. Since his childhood in the monastery he had been passionate for music until his disappearance and leaving a recorded tape in the car. This tape included a monologue in eight and a half pages [13, p. 12-21] without punctuation. In my view, this monologue shows the influence of the novel of Ulysses by James Joyce; it is similar to the monologue of Molly Bloom which is up to 45 pages [2, p.698-742] and both texts were written without punctuation marks or logical order, where the dream is mixed with the reality. The monologue of Walid Masoud was considered by the critic Shuja' al-'Anias the longest in the contemporary Arab novel. [14, p. 132]

In addition to the verbal tape, there was a musical tape found under the radio of the car, and the colour of the cassette which included the voice of Walid was red. This is a sign and a hint to the incident of disappearance of Walid, which was fraught with fear and crises by his friends. [13, p.7] This red mark of the cassette was repeated in Hunters in a Narrow Street before the suicide attempt of Adnan and Hussein when they heard the record of Hector Berlioz. The voice of Walid was recorded with music:

The music started, not very clearly, and Amer raised the volume. [13, p. 12]

The music on the tape was the Harpsichord Suites by the English composer Henry Purcell (1659-1695), well known for his dramatic composition and canticles.

Walid used to listen to music from the records of a phonograph [13, p.54] and practice his drawing hobby. Since his childhood Walid was originally called Khamis and, after a while, people started referring to him as Walid. He wanted to go to Milan to study and learn music. [13, p.74-75] Music has an important recreational function in his eyes. This is what he heard from Dr. Tariq Raouf when he was in his house last time and heard Purcell's Harpsichord Suites which was the last record that he bought:

Peace of mind? He said. You don't need music when you have peace of mind. [13, p. 118]

The referral to this record is a sign of departure, farewell, and anticipation to the disappearance of Walid. This is what Dr. Tareq felt:

The music blared out, but I didn't wait; I saw myself out to the sound of the music.

I hadn't learned anything new that evening. [13, p. 119]

Walid makes a parallel between his love to music and his homeland, both are similar for him and he is in a constant search for them: 
I longed for Baghdad. I longed for my home, for music, for the valley of Bethlehem, for Abu Dhabi, Beirut, Shemlan and Marwan! [13, p. 186].

Music for Walid has a relationship with sex, especially loud music which offers hints for sexual scenes. When he met Wisal Raouf in his car after spending the night listening to music and she read for him her poem with her breasts uncovered, he took her to his home to make love with her [13, p. 198]. It is interesting to note that loud and flagrant music was playing in every meeting between Walid and Wisal Raouf, as a hint for sexual scenes. Sex and music reached an ultimate moment in the surreal scene in which Walid started dancing to religious hymns in a concert hosted in Amer's house in Lebanon. After the departure of the visitors, he remained with Maryam Al-Saffar alone:

I felt the choral music blaring out of the tape deck was like nothing I'd ever heard before. It was, I knew, some kind of religious music. Walid loved, but I had little knowledge of it. He turned toward me and started swaying with music, singing along with it, his eyes fixed on me. Walid, I said, laughing, "Are you dancing to religious music?" "Can't you hear the choirs singing - in Latin, of course: "My soul praises the Lord because He chose me from among all women... and how else could praise be rendered except with song and dance?" [13, p. 168].

This dancing scene on the religious hymns was with a surreal nature, because it combines contradictory things, which are not related to each other in any way. In addition to being a way of worship and glorification of the Lord, with Walid it took on a cynical and sarcastic dimension when he used it for making love. Walid, cynical of religion, lived this surreal scene with Maryam al-Saffar who herself was infected with obsession and nervous spells. The loud religious music and her nervous spells, the movements and shouting of Walid during the dance, reflect Maryam's psychological crisis and foreshadow a strange scene in which Maryam started dancing naked between the garden trees and then came back to the bedroom carrying a stone to make love with Walid:

He fell over my breasts and lips and took me for the tenth time, yet as though it were the first time. I grabbed his hair and lifted his head to devour his mouth. From time to time I could see the rock behind him, sinking into the bed under its weight. [13, p. 171]

There is another recurring feature in this novel which is repeated throughout the works of Jabra. This was the interest in oriental music in particular by specific characters. When Dr. Jawad was driving his car together with Maryam al-Saffar, they listened to a sad song (Muwashah) full of nostalgia by the Lebanese singer Fairuz. The music helped Dr. Jawad to retrieve from his memory the event related to al-Hussein Ben Mansur al-Hallaj (858-922) one of the famous Sufis known for his love of music. He was accused of heresy and was executed. The incident refers to one of al-Hallaj's disciples who heard the sound of the Nay and asked his master what the noise was about:

"Al-Hallaj replied that it was the sound of Satan lamenting the destruction of the world he'd wanted to save. Satan was weeping, al-Hallaj told his disciple, because everything goes to perdition, whereas Satan wants to bring everything back to life, but that quality belongs to God alone." [13, p. 280]

The recovery of this incident at the end of the novel and the referral to the story of al-Hallaj while listening to music by Dr. Jawad gives the music a religious Sufi dimension, 
and hints to the disappearance of Walid Masoud as an inevitable thing, because everything goes to perdition from the standpoint of the Sufis and life belongs to God alone. This incident implied sad redolences to Dr. Jawad and Maryam al-Saffar as a result of the disappearance of Walid. Moreover, the use of the sound of the flute in this scene refers to the plaintive climate of the story, which describes death and extinction. The sad sound of the flute was appropriate for the event; it was employed to contribute to the explanation of the sad atmosphere in the novel.

\section{al-Ghuraf al-Ukhra [15] (The Other Rooms)}

The music is presented in this novel as it was presented in the previous novel "In Search of Walid Masoud" through a cassette recorder in a Mercedes driven by a girl. A schizophrenic man called Adel al-Teibi or Nimer Alwan was listening to a romantic piano nocturne by the Polish composer Frederic Chopin. While he was sitting in the Mercedes car with the girl and listening to this music, the moist Baghdad air revived his memory and retrieved the stored music in his memory and in particular Chopin's nocturnes:

I slipped into a deep cavern in my mind where I do not see or hear anyone. In this cave, I started now to enjoy the cold wet air that hits my face and hear the music I had been playing frequently in recent days -the Nocturnes of Chopin - which was part of my internal defence against the daily disruption in my life. [15, p. 16]

The function of music here is to sustain the human survival in the struggle against the disturbances in life. It is an element of subsistence and an incentive to survive. The choice of the text of a romantic piece of music by the composer Fredric Chopin in a deserted island to his mistress George Sand in a rainy and noisy night refers to a romantic and historical reference. It sheds light on the lives of Chopin and his mistress rich with music, sex, rain, and illuminated candles on the on hand, and reveals on the other hand the thoughts of Adel al-Tibi haunted by music and sex towards the driver of the Mercedes who shares his passion for the music of Chopin.

I imagined the young Chopin leaving the bed of his mistress George Sand in the darkness of "Mallorca" with the strident and torrential rain coming down on the deserted island. He was fumbling his way in the old rooms of the house with a candle light to the piano, to launch into its melodies with all his power in order to free himself from his illness and pain, even for just another night. [15, p. 16].

The establishment of relationship between the text of The Other Rooms and the nocturnes of Chopin which refer to the deteriorating health, suffering and sickness of Chopin, highlights the unconsciousness of Adel Tibi, who lives in harsh alienation, prosecutions and the torture of the secret services. He had changed his name and personality in order to be able to live in a world strange to him. The scene of events in the mind of Adel Tibi is a place different from the physical place in which he lives.

Chopin's nocturnes in this work, in addition to its artistic function in revealing the unconscious world of the characters, are used to overlook the alienation or isolation experienced by the characters in the place, like the Nocturnes that was referred to in order to free Chopin from his pain and illness. The driver of the Mercedes car owns dozens of cassettes of Western music implying that her wealth and social status are related to her love and knowledge of Western music. 


\section{Music in James Joyce'sDubliners [16]}

The use of music in fiction and short stories in order to revive the memory of the characters - to show their reflux and reveal their feelings and thoughts, is clearly reflected in my view in the works of James Joyce. His works are characterised by using reference to opera songs, ballads, amazing piano pieces and famous organ pieces in particular. In his collection of short stories the Dubliners (1914), composed of fifteen short stories, highlights an abundant use of music.

In his short story Eveline [16, p.36-41] James Joyce tells the story of a nineteen yearold girl living with her father who treated her brutally despite the death of her mother. However, she meets a young man working as a sailor called Frank who asked her to flee with him to his native home in Buenos Aires in Argentina. Eveline accepted to flee with Frank, however, one night before her departure with him, she listened to a street organ playing in the neighbouring street, which brought back the memory of her promise to her mother the night before her death to keep the family united. When she went with Frank to the station at North Wall, she decided not to sail with him and returned to her house despite the bitter life with her father and his cruelty towards her.

Down far in the avenue she could hear a street organ playing. She knew the air. Strange that it should come that very night to remind her of the promise of her mother, her promise to keep the home together as long as she could. She remembered the last night of her mothers' illness. [16, p.39-40]

The music influenced the events in the story, especially its planned end. It made Eveline back down from her trip with Frank. Frank also loves music, he used to sing her the song "The Lass that Loves a Sailor" [16, p. 39]. He also took her to the theatre to attend the opera of The Bohemian Girl ${ }^{3}$ written by the Irish musician and singer Michael William Balfe (1808-1870). The following clip in the song: "I dreamt that I dwelt in marble halls" $[16$, p.39], and the previous song are full of insinuation of her love to him, which means that music was an element which helped to reveal the personal feelings of Eveline toward Frank.

The use of lyrical text of operas linked to the characters is a phenomenon that is repeated in most of the works of Joyce. In the short story Clay [16, p. 99] the song of Michael Balfe which was mentioned in the story of Eveline is repeated in the words of Maria "I dreamt that I dwelt in marble halls". This song resuscitated the memories of Joe who shed tears on hearing it, and yearned avidly for the beautiful past. [16, p. 106]

In the story of "The Dead"[16, p. 175] there is an intensity in the use of music. Gretta with her husband Gabriel who is a university professor, stopped in a dark section of the hall, after the New Year's concert to listen from another room to Bartell D'Arcy singing "The Lass of Aughrim" and in particular to the clip:

"O, the rain falls on my heavy locks, and the dew wets my skin, my babe lies cold". [16, p. 218]

This song resuscitated the memory of Gretta and retrieved a love relationship that she lived in her youth with a boy named Micheal Furey who was always singing this song to her, but he died when he was seventeen years old. The text of the song which describes

\footnotetext{
3 It was presented for the first time in London in 1843.
} 
the rain on the locks of the hair and the yearning of the beloved, has a similar evocation on Micheal Furey, as narrated in the story, when he came to where she lives in the house of her grandmother and stood behind the window under the rain just shortly before his death. The music and the words of the song made Gretta cry, something which infuriated her husband while they were at the hotel after the New Year's concert. She admitted that she was thinking about that song which reminded her of someone, a young man named Micheal Furey, whom she had dated in her youth:

What about the songs? Why does that make you cry? She raised her head from her arms and dried her eyes with the back of her hand like a child. A kinder note than he had intended went into his voice. Why, Gretta? He asked: "I am thinking about a person long ago who used to sing that song, "Le me like a soldier fall". [16, p. 218]

The "Lass of Aughrim" mentioned five times in the story of "The Dead" conveys hints which refer to the death of Micheal Furey as well as death of the love relationship with her husband Gabriel. When Gabriel heard the song with his wife, he became excited and was overcome with love for her, and recalled scenes and images of the happy moments with her. [16, p. 213] But when his wife cried after hearing the song and told him the story of her love for Micheal Furey, he became indifferent and half-hearted towards her and both resorted to spiritual alienation. It is important to note that this song did not resurrect the memory of Gretta during the concert, but after it when she went with her husband to the hotel. There, through the retrieval of the concert events, especially the stored song in her memory, she changed her reaction and emotions towards her husband.

The critic Alex Aronson (1912-1995) called the music recovered of by Gretta from her memory after the concert in the story of "The Dead" a distant music or remembered music. He believes that listening to distant music, even if it was restored in the memory, represent two forms of mental contradiction, the first is the complete capitulation to the old melody that narrate the story of beauty, youth, love and the nostalgia to this beautiful past; and the second is the sudden awakening on the brutal reality experienced by the person, and the inability to convert his sensations to an integrated piece of music. [8, p. 43] Aronson believes that vigilance and awakening of the characters in the works of Joyce occurs after the end of the music, which quenches memory and dream and the character remain in the non-musical reality.[8, p.41] This is what happened to Gabriel and Gretta in "The Dead". Music made them remember the beauty, love, sweet past and the desire for sex. However, as the music ends, the cruel present was awakened and produced inside them aversion, indifference and spiritual alienation. For that reason, we notice that music in the Dubliners carried allegorical hints about the characters, contributed in shedding the light on their past and identity through recollections and resurrection of the memory.

\section{References}

1. Jabra I. Jabra. The Ship. Adnan Haydar and Roger Allen, trans. Colorado Springs, Three Continents Press, 1995.

2. Joyce James. Ulysses. New York, London, Garland Publishing, Inc., 1984.

3. Bowen Zack. Music and Leopold Bloom. Michigan University, Microfilms Inc., Ann Arbor, 1964.

4. Joyce James. Ulysses. New York, Random House Inc., 1961.

5. Webster Merriam. Encyclopedia of Literature. Springfield, Massachusetts, Springfield, 1995.

6. Ross Martin. Music and James Joyce. Norwood, Norwood Editions, 1978.

7. Jabra I. Jabra. Surākhfī Layl Ṭawīl [A Cry in a Long Night]. Beirut, Dar al-Adaab, 1988. (In Arabic) 
8. Aronson Alex. Music and the Novel: a study in Twentieth Century Fiction. Ottawa, New York, Rowman and Littlefield, 1980.

9. Jabra I. Jabra. Araqwa-Qișaș Ukhrā [Sweat and other Stories]. Beirut, Dar al-Adaab, 1989. (In Arabic) 1968.

10. Joyce James. A Portrait of the Artist as a Young Man. Harmondsworth, Middlesex, Penguin Books,

11. Holy Bible. The Old and New Testaments. London, The British and Foreign Bible Society, 1972.

12. Jabra I. Jabra. Hunters in a Narrow Street. London, Heinemann, 1960.

13. Jabra I. Jabra. In Search of Walid Masoud. Translated from the Arabic by Roger Allen and Adnan Haydar. Syracuse, N. Y, Syracuse University Press, 2000.

14. 'Ani Shuja'. Al-Bina' al-Fanni fi al-Riwayah al-Arabiyah fi al-Iraq [The Structure of the Arab Novel in Iraq]. Baghdad, Dar al-Kutubwa al-Watha'iq, 1994. (In Arabic)

15. Jabra I. Jabra. Al-Ghuraf al-Ukhrā [The Other Rooms]. Beirut, Al-Mu'asasah al-Arabyiahlil-Dirasatwa an-Nasher, 1986. (In Arabic)

16. Joyce James. Dubliners. New York, The Viking Press. 1969.

Для цитирования: Самир Хадж. Музыка в произведениях Джабры Ибрахима Джабры и влияние на него творчества Джеймса Джойса // Вестник Санкт-Петербургского университета. Серия 13. Востоковедение. Африканистика. 2016. Вып. 3. С. 86-100. DOI: 10.21638/11701/spbu13.2016.307

For citation: Samir Hajj. The Music in the Works of Jabra Ibrahim Jabra and the Influence of James Joyce's Writings. Vestnik of Saint Petersburg University. Series 13. Asian Studies. African Studies, 2016, issue 3, pp. 86100. DOI: $10.21638 / 11701 /$ spbu13.2016.307

Статья поступила в редакцию 21 апреля 2016 г.

Контактная информация

Samir Hajj — PhD; samirfus@gmail.com 